\title{
SZEMLE
}

\section{ISKOLÁK A JÁRVÁNY ALATT ÉS UTÁN - NEMZETKÖZI TAPASZTALATOK}

\author{
HARSÁNYI PÉTER \\ ELTE Szociológia Doktori Iskola \\ Beérkezett: 2021. január 18,, elfogadva: 2021. február 4.
}

Arthur K. Ellis \& Elizabeth Ebersole (eds): International Dialogues on Education: Past and Present, 2020. Volume 7. Special Issue [Schools, Education and the Pandemic of 2020]. pp. 6-80. ISSNः 2198-5944

2020 júliusában a Seattle Pacific University két munkatársa, Arthur K. Ellis és Elizabeth Ebersole online szimpóziumot szervezett Iskolák, oktatás és a 2020-as járvány címmel. Az ott elhangzott előadásokat az Internationals Dialogues of Education (IDE) folyóirat különszámában publikálták. Az írások a koronavírus miatti iskolabezárások pedagógiai, pszichológiai és társadalmi hatásait járják körül; egyaránt helyet kaptak közöttük filozofikus és tisztán leíró jellegű szövegek, de frissen végzett kvalitatív kutatások eredményeit is megismerhetjük. Az alábbiakban a különszám első kilenc cikkét mutatom be. Ezek többsége a német tapasztalatokon alapszik, de egy-egy szöveg erejéig az orosz és amerikai oktatási rendszerbe is bepillantást nyerhetünk.

$\mathrm{A} z$ első írás szerzője Jeremy Delamarker, a Washington állambeli Northwest University docense, aki a helyhez kötött oktatás szükségessége mellett érvel. Ezen nem feltétlenül a konkrét, fizikai jelenvalóságot, hanem sokkal inkább a résztvevők megismerési képességeinek, határainak elismerését érti. Nem egy komor iskolaépület, hanem az oktatásban részt vevők egymás iránti figyelmessége. Ebből következik, hogy az a neoliberális elvárás, miszerint az iskola feladata nemzetközi világpolgárok nevelése, a szerző szerint véghezvihetetlen. Hiszen a tanuló mindig valahol van és nem máshol: a túlságosan elvont és nehezen befogadható világ helyett ezért kis közösségekre kell alapozni az ismeretátadást. Delamarker meglátása szerint a tömeges iskolabezárások csak alátámasztják elképzelését. Személyes tapasztalata szerint az egyetemi hallgatók érzik, hogy az oktatás helyhez kötött tevékenység, ezért is szeretnének minél előbb visszatérni a kampuszokra.

A különböző online platformok használatával kapcsolatban szolgál pár tanácscsal Marianna E. Richardson, az utahi Brigham Young University adjunktusa. Nagyon fontos, hogy az intézmények tudatosan, előre kialakított stratégia mentén használják ezeket a felületeket, és az oktatókat teljes körűen megismertessék velük. A tanárokat a szerző arra figyelmezteti, hogy a megváltozott körülmények ellenére se felejtsék el a diákok aktív bevonását az órai munkába. Richardson borúlátó a járványt követő egyetemi életet illetően. $\mathrm{Az}$ 
eddig ismert laza, közvetlen és kampuszhoz kötött diák-tanár viszony távolságtartóbbá válhat, és ennek az intézmények tudományos munkája is kárát láthatja.

Alekszej Mihajlov és Marija Burlakova, az Ivanovói Állami Egyetem két docense azt mutatja be, hogyan reagált a Moszkvától mintegy 300 kilométerre fekvő város egyeteme a bezárásokat követő bizonytalanságra. Az írás a magyar felsőoktatás környékén megfordulók számára kevés újdonságot tartogat. Kiderül például, hogy komoly gondot jelentett az online platformok instabilitása, valamint a diákok és tanárok digitális képzetlensége, esetleg technikai ellátatlansága. Hetekig tartott, mire az intézmény elkezdte meghonosítani a beváltnak gondolt távoktatási gyakorlatokat, miközben igyekezett megtartani az egyetemen folyó tudományos kutatómunkát. A szerzők hozzáfüzik, hogy a vidéki orosz egyetemek anyagi támogatásra számíthatnak a közeljövőben. Ezt az ivanovóiak a diákok közötti technológiai egyenlőtlenségek csökkentésére és a hallgatók munkavállalásának segítésére szeretnék majd fordítani. Fejlesztés alatt áll továbbá egy új online platform is, mely a távoktatást hivatott megkönnyíteni. Ezt Mihajlov és Burlakova várakozásai szerint az Ivanovói Állami Egyetemen a világjárvány megszűnte után is alkalmazni fogják, párhuzamosan a személyes jelenlétet igénylő órákkal.

A következő írást a Pädagogische Hochschule Freiburg munkatársa, Fatima Chahin-Dörflinger jegyzi. Az általa vezetett kutatócsoport a pedagógusok szemszögéből vizsgálta az iskolabezárások hatását. Önértékelések megírására kértek fel számos tanárt, ügyelve arra, hogy lehetőleg minden iskolatípus bekerüljön a mintába. A 2020 áprilisa és júniusa között megírt önértékeléseknél figyelembe kellett venni többek között a felhasznált technikai eszközöket, a tanulók sajátos igényeinek online térben való felismerését, a lemorzsolódás megakadályozását, a visszacsatolást és az új kompetenciák fejlesztését. A Chahin-Dörflinger vezette kutatócsoport akciókutatást végzett, a kutatás eredményeit elsősorban a gyakorlatban szeretnék hasznosítani. Következtetéseiket is első körben az érintett intézményekkel osztották meg, hogy azok a további korlátozásokra már felkészültebben tudjanak reagálni. Az eredmények tudományos igényü publikálása nyáron még váratott magára.

Fabian Mußél, a magdeburgi Ottovon-Guericke-Universität doktorandusza és Maria Kondratjuk, a Technische Universität Dresden oktatója két konkrét vizsgálat bemutatásának apropóján elmélkednek a távoktatás kutatásának módszertani dilemmáiról. Három szempont szerint teszik fel továbbgondolásra ösztönző kérdéseiket. 1. A tanulók megváltozott időbeosztása egy rendkívül fontos, ám túlságosan is alábecsült probléma. Az átállás példátlan a modern német közoktatás történetében, ráadásul a tanárok számára is nehézségeket jelent. 2. A diákok és szülők is több támogatást vártak és várnak a pedagógusoktól a digitális oktatás során. A tanulók elsősorban azonnali visszacsatolást kívánnak a beadott feladatokról, a szülők pedig hasznos tanácsokat az együtt tanulásra. 3. A korlátozások miatt mindenki szomjazza a hús-vér emberrel való kommunikációt. Erre a távoktatás során különösképpen figyelni kell, már csak azért is, mert ez utóbbi a hagyományos iskolai szerepek fellazulásával jár. Azontúl, hogy a résztvevő kvalitatív módszer biztonságos és hatékony alkalmazása a járvány miatt megnehezült, a szerzők számos egyéb akadályt is azonosítanak. Például az iskolabezárások diákokra és tanárokra gyakorolt hatása az események után nem sokkal még igen nehezen mérhető fel, hiszen nem volt elég idő a történtek és tapasztalatok leülepedésére. A szerzők véleménye sze- 
rint ettől függetlenül a járvány jó alkalom az oktatáskutatók számára eddigi bevett módszereik megkérdőjelezésére, új módszerek kipróbálására, egyáltalánः a tanítás újragondolására.

Rövid írásában Dietmar Waterkamp, a Technische Universität Dresden nyugalmazott professzora arra mutat rá, hogy az iskolabezárásokat követő rendelkezések sokkal inkább tekinthetők pánikszerű reakciók sorának, mintsem kísérletezésnek. A fogalmakkal kapcsolatban tisztázza a táv-, online, digitális és otthonoktatás jelentését. Mivel a korábbiakhoz képest a jelenlegi helyzet legnagyobb újdonsága a digitális eszközök előtérbe kerülése, a digitális oktatás kifejezést érzi a legtalálóbbnak. Felhívja a figyelmet a deprivált csoportokat ért hátrányokra. A családon belüli erőszak növekedésével például olyan tanulók kerülnek a legkiszolgáltatottabb helyzetbe, akik számára az iskola korábban biztonságos helyet jelentett. A digitális oktatás a nem német anyanyelvű diákok számára külön nehézséget okozhat, hiszen kiesnek a napi nyelvhasználói rutinból.

A tanulók szüleit értintő stresszt vizsgálta Josephine Jeller és Heike Ohlbrecht az Otto-von-Guericke-Universitäten. Online kérdőívüket, melyben az iskolák bezárását követő egészség- és hangulatváltozásra kérdeztek rá, több mint kétezer német felnőtt töltötte ki (az adatok nem reprezentálják a teljes népességet). Ebből az derült ki, hogy bár a szülők körében csökkent a stressz és kimerültség érzése, növekedett a magány, a félelem és az általános elégedetlenség. A megkérdezettek több mint fele arról számolt be, hogy háztartásukban kizárólag a nő végzi a háztartási munkát és a gyermeknevelést. Ezzel egybecsengenek a kutatók eredményei is, miszerint az anyák sokkal inkább kitettek a stressznek, mint az apák. Csak azok számára jelentett stresszmentesebb időszakot a járvány, akik több minőségi időt tudtak családjukkal tölteni.

Olga Graumann, az Universität Hildesheim professor emeritája írását egy mindenki számára kényelmetlen kijelentéssel kezdi: "Járvány után is járvány elött leszünk - a COVID-19 minden valószinüség szerint nem az utolsó vírus, amely befolyással lesz az életünkre." A cikk a bezártság pedagógiai és pszichológiai hatásainak összefoglalása után ezért igyekszik konstruktív tanácsokkal szolgálni a jövőre nézve. Rövid távon a legfontosabb, hogy a tanulók újra személyesen találkozhassanak egymással és tanáraikkal. Ezt a szerző az iskolaépületek bővítésével, az osztályok szükítésével és intenzív teszteléssel tenné lehetővé, természetesen a higiéniai szabályok szigorú betartásával. Hosszú távon pedig a tanterv átalakítása is szükségessé válhat. Ebben Graumann szerint az idegen nyelvek és a matematika kivételével érdemes lenne minél kevesebb egymásra épülő tudást igénylő anyagot meghagyni. Ez megkönnyítené azoknak a tanulóknak a dolgát, akik egy esetleges újabb vírushelyzet miatt heteket, hónapokat lesznek kénytelenek jelenléti oktatás nélkül tölteni.

A müvészeti oktatás jövojéről ír Ann René Joseph, a Washington állami közoktatás-felügyelet egykori programvezetője. Egy 2020 tavaszán készült kvalitatív kutatás szerint az „Örökzöld állam” tanulói, szüleik, tanáraik, valamint a szakemberek mind meg vannak győződve arról, hogy a járvány utáni művészeti oktatás más lesz, mint korábban. Jelentős hányaduk arra számít, hogy valamiképpen az iskolaépületek is meg fognak változni, a csoportok létszáma csökkenni fog, a higiéniai szempontokat pedig sokkal erőteljesebben fogják érvényesíteni. Didaktikai szempontból sokan a személyre szabott oktatás előretörését jósolják. A jövőt illető bizonytalanság fóleg az interakciót igénylő ágak művelőinél (zenekari tagok, színé- 
szek, táncosok) figyelhető meg. A szerző szerint a müvészeti tárgyak a tanulók szociális életére, érzelmi intelligenciájára és kognitív fejlődésére is jó hatással vannak, ezért mindenképpen fontos a müvészeti oktatás jövőjéről való gondolkodás.

A fent bemutatott szövegek rendkívül sokfelé mutatnak. Noha céljaik és kérdésfeltevéseik jórészt különböznek, távlatuk közös: a jelenlegi helyzet bemutatása után mindegyik megfogalmazza elképzelését a járvány utáni oktatásról. Hozzáállás kérdése, hogy a szerzők felfrissült, jobban működő iskolákat vagy egymástól elszigetelt, egy helyben topogó tanárokat és diákokat jósolnak-e. Abban viszont, hogy az iskolabezárások hatására az oktatás soha nem látott mértékben és ütemben meg fog változni, mind egyetértenek.
Nemcsak azért izgalmas olvasni ezt a kilenc írást, mert a miénktől valamenynyire eltérő oktatási rendszerek reakcióit mutatja be. Felemelő látni, hogy a lezárások bejelentése után alig négy hónappal a kutatók már kész eredményekkel, jól megfogalmazott, a laikusok számára befogadható, de a tudományosság kritériumainak is megfelelő szövegekkel álltak elö. Igaz, a szerzők ilyen tempó mellett néhány esetben a kutatások módszertani elvárásainak nem mindenben tudtak megfelelni: előfordultak túlságosan szűk körű mintavételek, egymást részben fedő kérdések, a súlyozás hiánya. Mindezek ellenére az IDE koronavírus-különszáma magas színvonalú, elgondolkodtató és fóleg - friss írásokból áll.

A cikk a Creative Commons Attribution 4.0 International License (https://creativecommons.org/licenses/ by-nc/4.0/) feltételei szerint publikált Open Access közlemény, melynek szellemében a cikk bármilyen médiumban szabadon felhasználható, megosztható és újraközölhető, feltéve, hogy az eredeti szerző és a közlés helye, illetve a CC License linkje és az esetlegesen végrehajtott módosítások feltüntetésre kerülnek. 